\title{
インフレーション成形の粘弾性解析
}

\author{
篠 原正之*1 - 梶原稔尚*2 - 船津和 守*3
}

\section{Viscoelastic Analysis of Tubular Film Blowing}

\author{
SHINOHARA, Masayuki*1/KAJIWARA, Toshihisa*2/FUnATSU, Kazumori*3
}

In this research, we investigated the dependence of stress anisotropy and bubble shape on Weissenberg number and degree of non-linearity at a fixed bubble radius and thickness in tubuler film blowing. The process was analysed by the Maxwell model and Larson model. Conclusions were as follows. (1) As the Weissenberg number increases at a fixed bolw-up ratio and draw down ratio, the stress ratio at the freezeline increases and a neck in the bubble vanishes for the Maxwell model. (2) Stress could be calculated to realistic draw down ratio by introducing non-linear constitutive equations into the film blowing analysis. (3) As the non-linear parameter increases at a fixed blow-up ratio and draw down ratio, stress anisotropy increases and the length of neck increases.

Key words : Tubuler film blowing/Viscoelasticity/Larson model

\section{1. 緒言}

インフレーション成形は T ダイキャストやシート 成形とならんで高分子フィルムの代表的成形法である. 高密度ポリエチレン (HDPE) の場合, 全用途の $40 \%$

*1 出光石油化学(製) 樹脂研究所

市原市姉崎海岸 1-1（宁 299-01）

Polymer Research Laboratory, Idemitsu Petrochemical Co., Ltd.

1-1 Anesakikaigan, Ichihara, Chiba 299-01 Japan

*2 九州大学 工学部 化学機械工学科

現・九州工業大学 工学部 物質工学科

北九州市戸畑区仙水町 1-1 (

Department of Chemical Engineering,

Kyushu University

Present affiliation

Department of Applied Chemistry,

Kyushu Institute of Technology

1-1 Sensui-cho, Tobata-ku, Kitakyushu, Fukuoka

804 Japan

*3 九州大学 工学部 化学機械工学科

福岡市箱崎 6-10-1 (广 812)

Department of Chemical Engineering,

Kyushu University

6-10-1 Hakozaki, Higashi-ku, Fukuoka 812 Japan 1996.10.8 受理
程度がインフレーション成形によって製品化されてい る.

インフレーション成形の概要を Fig.1 1 示した. 二 重円筒状のダイから出た溶融樹脂に内圧を掛けて膨張 させ，同時にローラーで連続的に引き取り，円筒状の フィルムを製造する成形法である，膨張した溶融樹脂 をバブルと呼ぶ。バブルはエアリング (air-ring) から の冷却風によって冷却され，フロストラインと呼ばれ る固化領域を経て，ローラーで巻き取られる．フロス トラインまでの膨張比とローラーの巻取速度を調節す ることにより，様々な幅と厚さのフィルムが製造でき る点がインフレーション成形法の特徵である.

また，インフレーション成形は典型的な一軸ないし 二軸の伸長プロセスであり，膨張比や延伸比，フロス トライン高さにより, フィルムの特性を変化させるこ とができる. 特に力学的諸物性は重要な要求特性であ り, 衝撃強さ, 引張強さ, 引裂強さ, 弾性率などがある. これらフィルムの性質は前述の成形操作因子と材料 のレオロジー的性質に依存するため, インフレーショ ン成形をモデル化し，理論的に解析する研究が行われ てきた.インフレーション成形のモデル化を最初に 


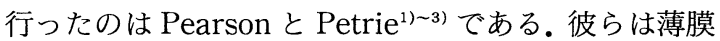
を仮定した支配方程式を導き，等温 Newton 流体によ る解析を行った. $\mathrm{Han}^{4)}$ は, power-law モデルで解析 した. 金井(5) て7) White は, 結晶化過程を取り入れた 非等温 Newton 流体による解析を行った。

粘弾性解析の研究は, Maxwell モデルを用いた解析

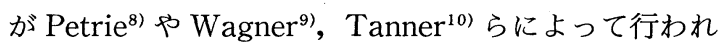
ている. 最近 Denn ら ${ }^{11)}$ は, Maxwell モデルなどを用 い，数值計算の詳細な結果を報告している. Campbell ${ }^{12)}$ らは, フロスト付近に二相モデルを導入し, 解析 している.

以上, インフレーション成形の解析は着実に進歩し てきた. しかしながら, 金井らの解析を除いて, 同一 の成形条件で材料のレオロジー的性質と成形挙動の関 係を検討した例はほとんどない。

本報では, 非線形粘弾性モデルをインフレーション 成形モデル ${ }^{1) \sim 3)}$ に取り入れることにより, 同一成形条 件下における応力とバブル形状の粘弾性的性質依存性 について検討した結果を述べる. 製膜時の応力は平均 的な分子の配向と関係し, 最終製品の力学的性質に大 きく影響すると考えられる。

\section{2. インフレーション成形のモデル化}

\section{1 座標および変形速度テンソル}

解析のための座標系を Fig.2 に示した。座標の設定 は従来の方法に従った。

ダイの中心から押出方向に $z$ 軸をとり, バブルは $z$ 軸に対して対称であるとした。いっぽう，バブル表面 に局所座標系 $(s, t, n)$ を取り， $s$ をバブルの縦方 向, $t$ を横方向, $n$ を厚み方向とした。 $t$ は座標を右手 系とした場合, 図の紙面に垂直下向きの方向とした。

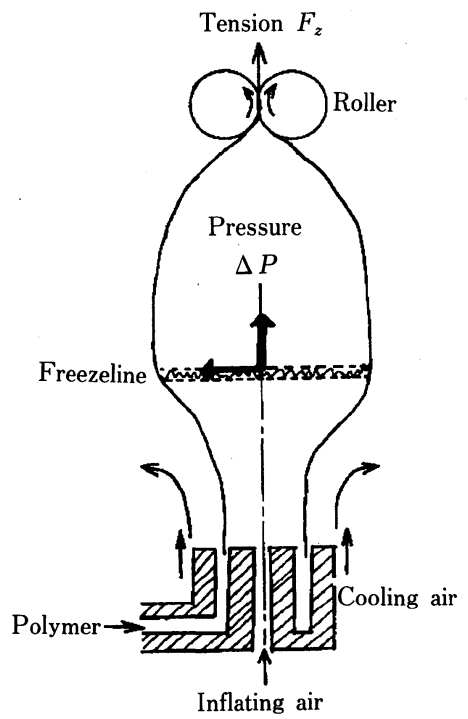

Fig.1

Schematic of film blowing process
位置 $z$ におけるバブルの半径を $R$ ，厚みを $H$ とした。 バブルが $z$ 軸に対称であることを仮定したので, $R(z)$ および $H(z)$ である. フロストラインの位置 $z=z_{\mathrm{f}}$ に おける半径および厚みを $R_{\mathrm{f}}, H_{\mathrm{f}}$ とした。

$v_{s}$ を縦方向の速度とすると, バブル表面の各位置に おいて,

$$
2 \pi R H v_{s}=q
$$

が成立する。ここで, $q$ は単位時間当たりの流量であ り, 定常状態では一定である.（1)式は, 連続の式(質 量保存則）を表している。（1）式を $s$ で微分すること により,

$$
\frac{\mathrm{d} v_{s}}{\mathrm{~d} s}=-\frac{1}{H} v_{s}-\frac{\mathrm{d} H}{\mathrm{~d} s}-\frac{1}{R} v_{s} \frac{\mathrm{d} R}{\mathrm{~d} s}
$$

が得られる. 左辺は $s$ 方向のひずみ速度であり, 右辺 第 1 項は厚み方向のひずみ速度に負号をつけたもの, 第 2 項は半径方向のひずみ速度に負号を付けたもので ある. (2) 式を用いて, 変形速度テンソル $\boldsymbol{D}$ は次式で 表される。

$$
\boldsymbol{D}=\frac{q \cos \theta}{2 \pi R H}\left[\begin{array}{ccc}
-\left(\frac{H^{\prime}}{H}+\frac{R^{\prime}}{R}\right) & 0 & 0 \\
0 & \frac{H^{\prime}}{H} & 0 \\
0 & 0 & \frac{R^{\prime}}{R}
\end{array}\right]
$$

\section{2 運動量およびエネルギー保存式}

力のバランス式は薄膜を仮定した以下の 2 式を用い た.

$$
\begin{gathered}
\frac{\Delta P}{H}=\frac{\sigma_{s}}{\rho_{t}}+\frac{\sigma_{s}}{\rho_{t}} \\
-\pi R^{2} \Delta P+2 \pi R H \sigma_{s} \cos \theta=F_{z}-\pi R^{2} \Delta P
\end{gathered}
$$

(4) 式はバブルの厚み方向の力のバランス式であ $\eta, \Delta P$ はバブル内圧, $\sigma_{s}, \sigma_{t}$ は $s$ 方向および $t$ 方向の 応力, $\rho_{s}$ と $\rho_{t}$ は $s$ 方向抢よび $t$ 方向の曲率半径であ

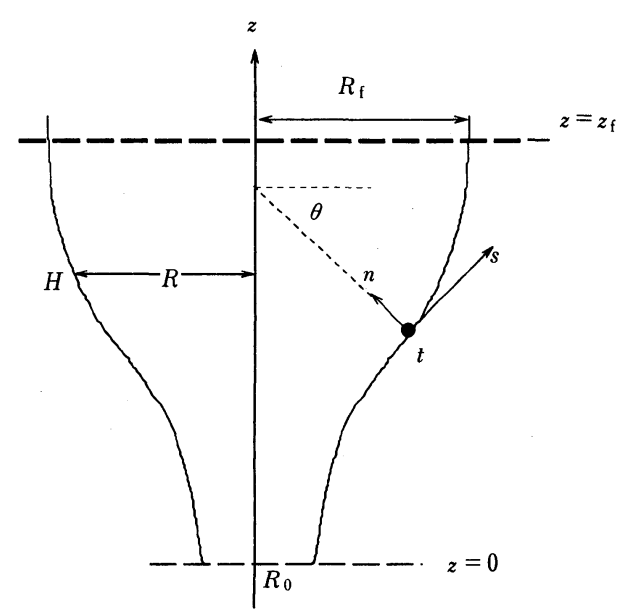

Fig.2 Coodinate systems of film blowing 
る.

$$
\begin{aligned}
& \rho_{s}=-\frac{\left\{1+\left(\frac{\mathrm{d} R}{\mathrm{~d} z}\right)^{2}\right\}^{3 / 2}}{\frac{\mathrm{d}^{2} R}{\mathrm{~d} z^{2}}} \\
& \rho_{t}=R\left\{1+\left(\frac{\mathrm{d} R}{\mathrm{~d} z}\right)^{2}\right\}^{1 / 2}
\end{aligned}
$$

(5) 式は $z$ 方向の力のバランス式である. $F_{z}$ はピン チローラーから与えられる $z$ 方向の張力であり, $\cos \theta$ はFig.2 に示したように,

$$
\cos \theta=R\left\{1+\left(\frac{\mathrm{d} R}{\mathrm{~d} z}\right)^{2}\right\}^{-(1 / 2)}
$$

で与えられ，局所座標系の諸量を $z$ の関数に変換する ために用いる。

エネルギー保存則として,

$$
\rho C_{\mathrm{p}} q \cos \theta \frac{\mathrm{d} T}{\mathrm{~d} z}=-2 \pi R U\left(T-T_{\mathrm{a}}\right)
$$

を仮定した． $\rho$ は溶融密度， $C_{\mathrm{p}}$ はポリマーの熱容量, $U$ は総括伝熱係数, $T$ はバブル温度, $\mathrm{T}_{\mathrm{a}}$ は冷却空気の 温度である。（9)式は熱伝達の主要な因子として対流 伝熱のみを取り入れたモデルである.

\section{3 構成方程式の選定}

構成方程式は別報 ${ }^{13)}$ で検討した緩和モード以外の 一つのフィッティングパラメーターをもつ微分型の中 から，Larsonの式を選定して用いた，別報の結果よ り，一軸伸長流動下における定常伸長粘度の予測性能 は各粘弾性モデルにより大きく異なっている．本報の 目的の一つである製膜時の応力予測のためには，高延 伸倍率時すなわち定常状態に近いひずみ領域における 伸長粘度の予測性能が重要であり,この点で Larson モデルが最適と考えられた。

Larson モデルは次式で表される。

$$
\boldsymbol{\tau}+\lambda \frac{\delta \boldsymbol{\tau}}{\delta t}+\frac{2 a \lambda}{3 G} D: \boldsymbol{\tau}(\boldsymbol{\tau}+G \mathbf{1})=2 G \lambda D
$$

ここで, $\tau$ は余剰応力テンソル, $\lambda$ は緩和時間, $G$ は 弾性率, $\alpha$ は非線形パラメーター, 1 は単位テンソルで ある。また， $\delta / \delta t$ は対流微分であり， $D: \tau$ は $\operatorname{tr}(D$. て）を表す（10）式は非線形性の影響を検討するため に用いた，緩和時間の影響を検討する場合には，(10) 式で $\alpha=0$ と置いた Maxwell モデルを用いた.

$$
\tau+\lambda \frac{\delta \tau}{\delta t}=2 G \lambda D
$$

余㮃応力テンソルと応力テンソルの関係は,

$$
\sigma=-p \mathbf{1}+\boldsymbol{\tau}
$$

である.ここで， $p$ は内部圧力である.

緩和時間の温度依存性は Arrhenius 型を仮定した。

$$
\lambda=\lambda_{0} \exp \left\{\frac{E}{R}\left(\frac{1}{T}-\frac{1}{T_{0}}\right)\right\}
$$

ここで， $\lambda_{0}$ は基準温度における緩和時間であり， $E$ は流動の活性化エネルギーである.

\section{4 無 次 元 化}

変形速度テンソルの式 (3) 式を構成方程式 (10) または（11）式に代入し，（4）式，（5）式，（9）式 と組み合わせることによって支配方程式が得られる。 独立変数 $z$ に対し, 従属変数は $\sigma_{s}, \sigma_{t}, p, R, H, T$ である.

これらの量を代表長さ $R_{0}$, 代表速度 $v_{\mathrm{e}}$, 代表温度 $T_{\mathrm{a}}$, ゼロせん断粘度 $\eta_{0}$ で無次元化した。 $R_{0}$ は夕゙イの 半径, $v_{\mathrm{e}}$ は押出線速度である. 応力, 緩和時間につい ては通常と同様である.ただし, Weissenberg 数は $\bar{\lambda}$ で表した. Weissenberg 数の定義式は，

$$
\bar{\lambda}=\frac{\lambda v_{\mathrm{e}}}{R_{0}}
$$

である。

成形操作に関係したパラメーターは,

$$
\begin{gathered}
B=\frac{\pi R_{0}{ }^{3} \Delta P}{\eta_{0} q} \\
T_{z}=\frac{R_{0} F_{z}}{\eta_{0} q} \\
C_{h}=\frac{2 \pi R_{0}{ }^{2} U}{\rho C_{\mathrm{p}}}
\end{gathered}
$$

フィルムのサイズに関係したパラメーターは,

$$
\begin{aligned}
& \bar{R}_{\mathrm{f}}=R_{\mathrm{f}} / R_{0} \\
& \bar{H}_{\mathrm{f}}=H_{\mathrm{f}} / H_{0}
\end{aligned}
$$

である.ここで， $H_{0}$ はダイクリアランスである。

$R_{\mathrm{f}}$ を通常，ブロー比と呼ぶ．また，バブルの引き取 り速度を $v_{\mathrm{f}}$ とした時, $v_{\mathrm{f}} / v_{0}$ をドロー比と呼ぶ. ドロー 比は, $\bar{R}_{\mathrm{f}} お$ よ゙゙ $\bar{H}_{\mathrm{f}}$ と

$$
\frac{v_{\mathrm{f}}}{v_{0}}=\frac{1}{\bar{R}_{\mathrm{f}} \bar{H}_{\mathrm{f}}}
$$

の関係にある。

また，温度 $T$ は，

$$
\bar{T}=\frac{T-T_{\mathrm{a}}}{T_{\mathrm{a}}}
$$

とした。 なお，位置 $z$ は $X=z / R_{0}$ とした。

\section{3. 計 算 方 法}

5 個の連立常微分方程式を以下の境界条件で解いた。

$$
\left.\left.\begin{array}{rl}
\bar{R} & =1 \\
\bar{H} & =1 \\
p & =0 \\
\sigma_{t} & =0 \\
R^{\prime} & =R^{\prime}{ }_{0} \\
\bar{T} & =T_{0}
\end{array}\right\} \text { at } X=0 \quad \begin{array}{c}
\bar{R}=\bar{R}_{\mathrm{f}} \\
\bar{H}=\bar{H}_{\mathrm{f}} \\
R^{\prime}=0 \\
\bar{T}=\bar{T}_{\mathrm{f}}
\end{array}\right\} \text { at } X=X_{\mathrm{f}}
$$

$T_{0}$ は押出温度を（18）式に入れた值であり， $R_{0}^{\prime}$ は ダイ出口における半径の増加率である. 


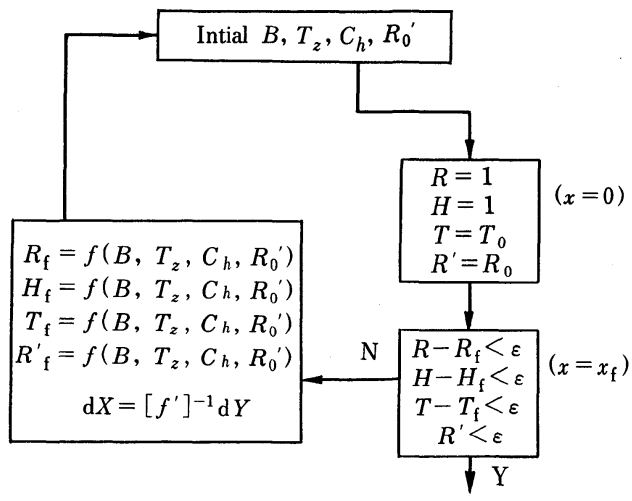

Fig.3 Scheme of the calculation method

計算のフローを Fig. 3 に示した．従来の報告では， $B$ と $T_{z}$ を一定としてフロストラインにおける $R_{\mathrm{f}}, H_{\mathrm{f}}$ を求めているものが大半であった。しかしながらこの 方法ではフィルムサイズを同一とした時の材料の溶融 粘弾性的性質と成形性の関係を検討することができな い. また, 実際のインフレーション成形の操作でも, 所定のサイズのフィルムを得るためにバブル内圧と冷 却風の量を調節する．そこで本検討では，計算方法に ついても実際の成形操作と同様となるようにした。こ の方法は金井7)の方法を，粘弾性流体に拡張したもの である。

最初にパラメーター $B, T_{z}, C_{h}, R_{0}{ }^{\prime}$ に適当な值を入 れ, $X=0$ から $X=X_{\mathrm{f}}$ まで積分する. 結果を所定の境 界条件と比較し，境界条件を満たさない場合には，4 種のパラメーターをわずかに増加させて偏微分係数 ${f^{\prime}}^{\prime}{ }_{i j}$ を求める.ここで, ${f^{\prime}}^{\prime}{ }_{i j}$ は $X=X_{\mathrm{f}}$ における境界条 件を列ベクトル $Y$, パラメーターを列ベクトル $X$ と したとき，

$$
\mathrm{d} Y=\left[f^{\prime}\right] \mathrm{d} X
$$

で表される行列の要素である。改良されたパラメー ターは,

$$
\mathrm{d} X=\left[f^{\prime}\right]^{-1} \mathrm{~d} Y
$$

より得られる。このステップを境界条件を完全に満た すまで繰り返し, 同時に最適パラメーター值も求めた.

\section{4. 結果と考察}

\subsection{Weissenberg 数依存性}

Fig. 4 にブロー比とドロー比を一定とした場合のバ ブル形状の Weissenberg 数依存性を示した. Maxwell モデルを用いた. HDPE を想定した流動の活性化エネ ルギーと $T_{\mathrm{f}}$ の值を用いた。横軸に規格化した半径を, 縦軸に規格化した位置を取り，実際の成形と同様に見 えるように図示した。

Weissenberg 数を増加させるに従って, バブル形状

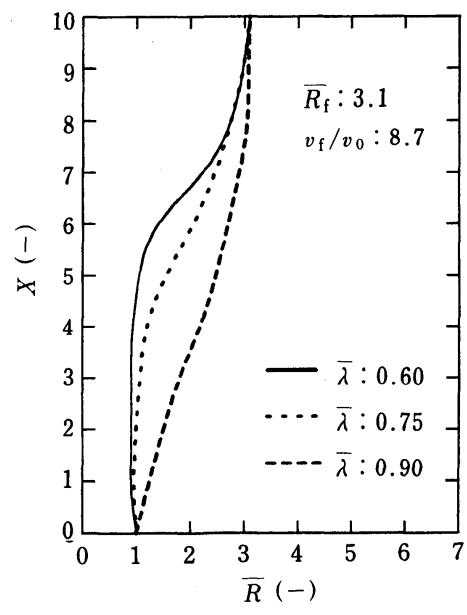

Fig.4 Dependence of the bubble shapes on Weissenberg number under constant draw ratio and blow-up ratio by using the Maxwell model

はワイングラス型から首の太い形状に変化した。従来 の報告では流動の活性化エネルギーを大きくするに 従って, ワイングラス型から首の太い形状に変化する ことが知られている。典型的な例はポリエチレンであ り，HDPE の場合にはワイングラス型，LDPE の場合 には首の太い形状である。この結果は, Weissenberg 数の増加によっても同様の現象が起こることを予測し ている. 流動の活性化エネルギーの増加と Weissenberg 数の増加はどちらも伸長応力の増加をもたらす. したがって，フロストラインに近くなるほど変形しに くい. 同一のフィルムサイズで比較した場合, ダイを 出てから比較的初期の段階で変形するためと考えられ る.

Fig.5 にブロー比とドロー比を一定とした場合のフ ロストラインに抢ける縦方向, 横方向の応力とそれら の比を示した. フロスト付近における応力は固化時の 応力と密接に関係し, したがって, 製品となったフィ ルムの力学的性質に強く影響するものと考えられる。 図中の MD は縦方向を意味し，TD は横方向を意味す る. Weissenberg 数の増加とともに, 縦方向の応力は 増加し，横方向の応力は減少していく．結果的に応力 の異方性は増加していくことが予測された，実際のイ ンフレーション成形で製造されたフィルムの場合にも， 分子量分布の広いものほど製品の力学的異方性が大き いことが知られている．分子量分布の拡大によって緩 和時間分布も拡大するので, 平均の Weissenberg 数も 増加すると考えられる，この結果は定性的に実際の現 象と一致している. 


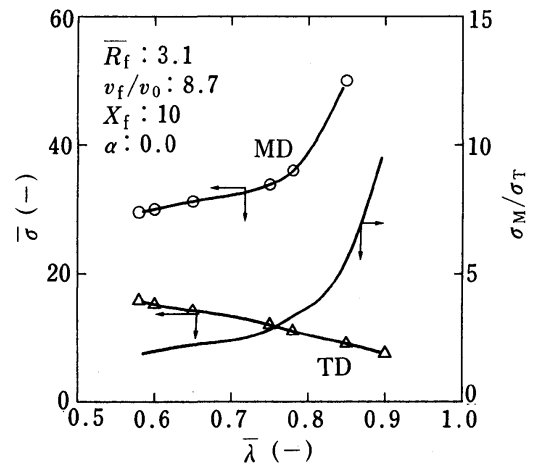

Fig.5 Dependence of stresses in the direction of $M D$ and TD on Weissenberg number under constant draw ratio and blow-up ratio

Table 1 Effect of varying non-linear parameter $\alpha$

\begin{tabular}{c|c|c|c|c}
\hline$\alpha$ & 0.0 & 0.01 & 0.05 & 0.20 \\
$\bar{R}_{\mathrm{f}}$ & 2.79 & 2.71 & 2.50 & 2.15 \\
$\bar{H}_{\mathrm{f}}$ & 0.023 & 0.021 & 0.020 & 0.008 \\
$v_{\mathrm{f}} / v_{0}$ & 15.6 & 17.6 & 20.0 & 58.0 \\
\hline
\end{tabular}

\section{2 非線形パラメーター依存性}

Fig. 6 は，バブル形状の非線形パラメーター依存性 を示したものである.この図のみ, Tanner らの結果と 比較するために, $B, T_{z}$ を一定として等温状態を仮定 して計算した。非線形パラメーター $\alpha=0.0$ の結果は Tanner らの結果と一致し，計算プログラムの有効性 が確かめられた。非線形性を大きくするに従ってブ ロー比は小さくなった。しかしながら，非線形性を大 きくした効果はドロー比に著しく現れた. Table 1 は 非線形パラメーターを増加させた場合のブロー比とド ロー比を示したものである. $T_{z}$ 一定でも非線形性が大 きくなるに従ってドロー比が大きく増加した．実成形 におけるドロー比は数十から 100 程度であり, 非線形 構成方程式をインフレーション成形の粘弾性解析に取 り入れることにより，より実際に即した計算が可能と なることが明らかとなった。

Fig.7 はブロー比，ドロー比を一定とした場合の無 次元化したバブル引取力 $T_{z}$ を Maxwell モデルおよ び Larson モデルで比較した結果である. Maxwell モ デルではドロー比が比較的小さいうちに無限大の力が 必要となってしまい, 計算不可能となる。これは,こ のモデルの伸長応力がひずみ速度が大きくなると無限 大となるためである。いっぽう, Larson モデルは比較 的実験結果に近いオーダーのバブル引取力を予測する。

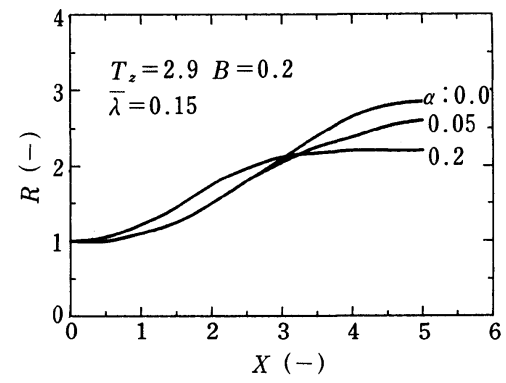

Fig.6 Dependence of the bubble shapes on non-linear parameter under constant dimensionless bubble tension and internal pressure

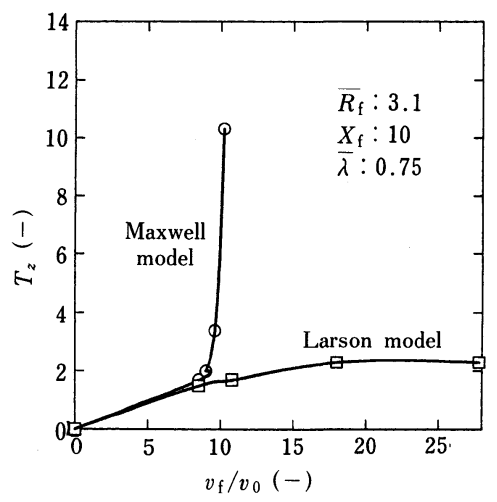

Fig.7 Comparison of dimensionless bubble tension $T_{z}$ on drawdown ratio between the Maxwell model and the Larson model

非線形モデルの導入により，高いドロー比まで計算可 能となった理由は，非線形モデルの予測応力が無限大 とならず，実際に近いためである.

Fig. 8 はフロストラインにおける緹方向と横方向の 応力と非線形パラメーターの関係を示したものである。 非線形性が増加するに伴ってそれぞれの応力は減少す る.

Fig.9 に応力の比と非線形パラメーターの関係を示 した. 非線形性が強くなるに従って製膜時の応力の異 方性が強くなっていくことが予測された。一般にせん 断粘度の非 Newton 性が強いほどフィルムの力学的 性質の異方性も強くなることが知られている。この結 果も定性的に実際の現象と一致した。

Fig.10にバブル形状の非線形パラメーター依存性 を示した。非線形性が大きいほどバブルの首は長くな り，いわゆるネックイン現象が激しくなることが予測 された. 4.1 節の Weissenberg 数とバブル形状の結果 と併せて考察すると，ネックイン現象には緩和時間と 


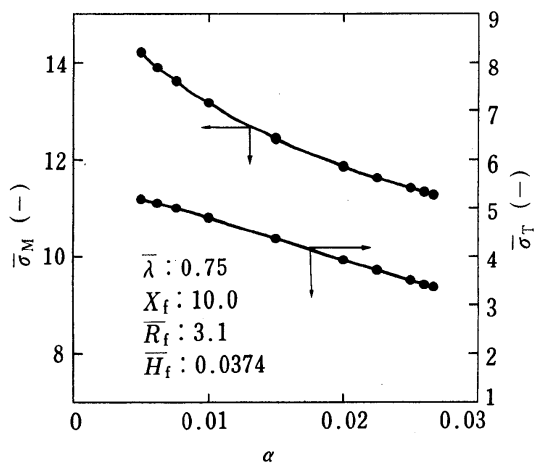

Fig.8 Dependence of stresses in the direction of MD and TD on nonlinear parameter under constant draw-down ratio and blow-up ratio

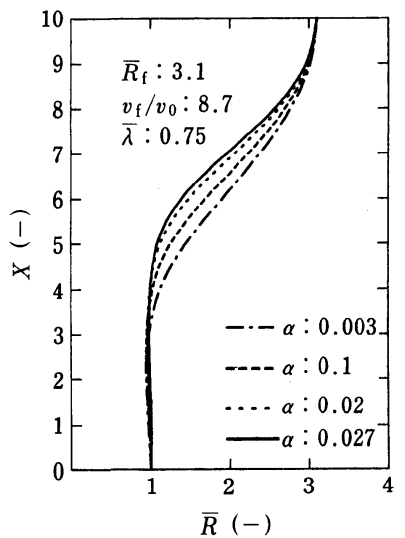

Fig. 10 Dependence of the bubble shapes on nonlinear parameter under constant draw-down ratio and blow-up ratio

$\bar{R}(-)$

非線形度の両方が影響することが予測された。

\section{3 バブル温度の予測性能}

以上， 4.1 節および 4.2 節でパラメーターと成形性 の関係について検討してきたが，本解析が非等温で行 われているため，同時に算出されるバブル温度の妥当 性を確認する必要がある. Fig.11にバブル温度の計算 值を示した，HDPE は結晶性高分子であり，温度は夕゙ イからの距離とともに直線的ないしはやや上に凸の曲 線で減少したのち，フロストラインの直前で一定と

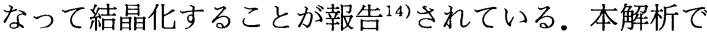
はフロストラインで一定値になるようにしたが，得ら れた温度プロファイルはやや上に凸の曲線であり，現 象と定性的に一致しており, 妥当であると判断された。

\section{4 実験との比較}

2 種の HDPE を用いて，予測結果を実験と比較し た。試料 $\mathrm{A}$ は $M_{w} 275000, M_{w} / M_{n} 27.2$ であり, 試料 $\mathrm{B}$ は $M_{w} 254000, M_{w} / M_{n} 28.7$ である.動的粘弾性はレ オメトリックス社製システム 4 で測定した。結果を

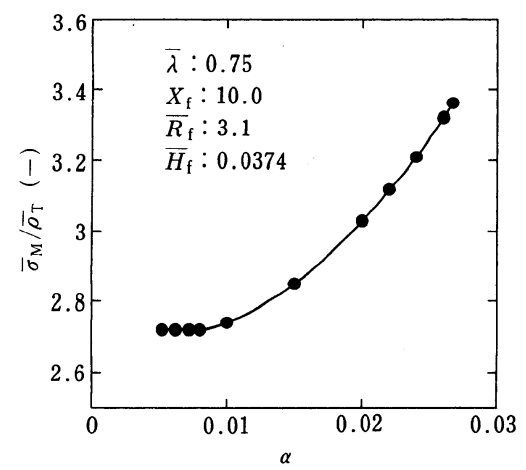

Fig.9 Dependence of stress ratio at the freezeline hight on nonlinear parameter

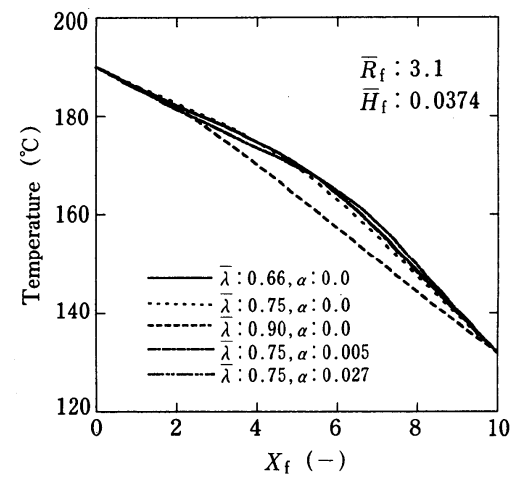

Fig.11 Calculated temperature profile under various conditions

Fig.12 に示した. 動的弾性率. $G^{\prime}$ の結果から緩和スぺ トクルの分布は $\mathrm{A}$ のほゔ $\mathrm{B}$ よりも広く, 平均の Weissenberg 数は $\mathrm{A}>\mathrm{B}$ である。また複素粘性率に Cox-Mertz 則を仮定すると非 Newton 性もA のほう が大きい.

インフレーション成形は実験用の小型装置で行った。 Fig. 13 に概要を示した.ダイの直径は $1.7 \mathrm{~cm}$, ダイク リアランスは $0.067 \mathrm{~cm}$ である. バブル引取力は「て こ」の原理を用いて，張力計である LVDT で測定し た。バブル内圧はダイ中心にある空気吹込用のライン と連結させたマノメーターで測定した。押出温度は $190^{\circ} \mathrm{C}$ し，押出量は $20 \mathrm{~g} / \mathrm{min}$ とした。ブロー比は 3.1 ，ドロー比は 8.7 とした。フロストライン高さは $8.5 \mathrm{~cm}$ とした。

結果を Table 2 に示した。（4）と（5）式よりフロ ストラインにおける縦方向と横方向の応力の比は,

$$
\frac{\sigma_{s}}{\sigma_{t}} \propto \frac{F_{z}}{\Delta P}
$$

となることがわかる. 試料 A は B よりも Weissenberg 


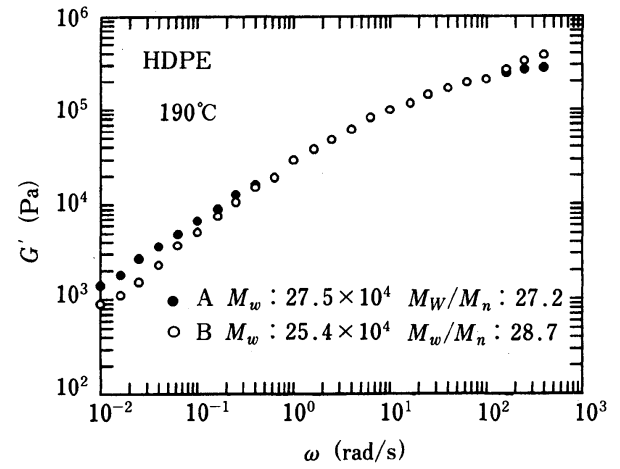

Fig.12 Dynamic viscoelastic properties of HDPE

Table 2 Bubble tension and internal pressure of HDPE

\begin{tabular}{c|c|c|c|c}
\hline Sample & $F_{z}(\mathrm{~g})$ & $\begin{array}{c}\Delta P \\
(\mathrm{~cm})\end{array}$ & $F_{z} / \Delta \mathrm{P}$ & $\begin{array}{c}\text { Tear strength ratio } \\
(\mathrm{TD} / \mathrm{MD})\end{array}$ \\
\hline $\mathrm{A}(\mathbf{O})$ & 280 & 9 & 31 & 11.0 \\
$\mathrm{~B}(\mathrm{O})$ & 260 & 11 & 24 & 7.5 \\
\hline
\end{tabular}

数が大きく，非線形性も大きい.どちらの効果がより 支配的な因子かは目下のところ判断できないが， $F_{z} /$ $\Delta P$ は $\mathrm{A}$ が $\mathrm{B}$ より大きく, 予測結果と測定結果は定性 的に一致した. また, フィルムの引裂強度の比も $\mathrm{A}$ が $\mathrm{B}$ 上り大きく, $F_{z} / \Delta P$ の大小関係と一致した.

\section{5. 結言}

インフレーション成形モデルに非線形粘弾性モデル を取り入れ，定常非等温解析を行い，以下の結論を得 た。

（1）ブロー比とドロー比を一定とした場合，Weissenberg 数が増加するに従ってバブル形状はワ イングラス型から首の太い形状へ変化した。また フロストラインの応力の異方性が急激に増加した。

(2) 非線形粘弾性モデルを取り入れた結果, より実 用的なドロー比まで計算することができた。

（3）ブロー比とドロー比を一定とした場合，非線形 性が増加するに従って，バブル形状はより首の長 い形状へ変化した。 また，フロストラインにおけ る応力の異方性は大きくなった。

(4) 小型成形機により, 計算条件と同一の条件で成 形した結果, 予測結果と実験結果は定性的に一致 し，本報のモデルの有効性が確認された。

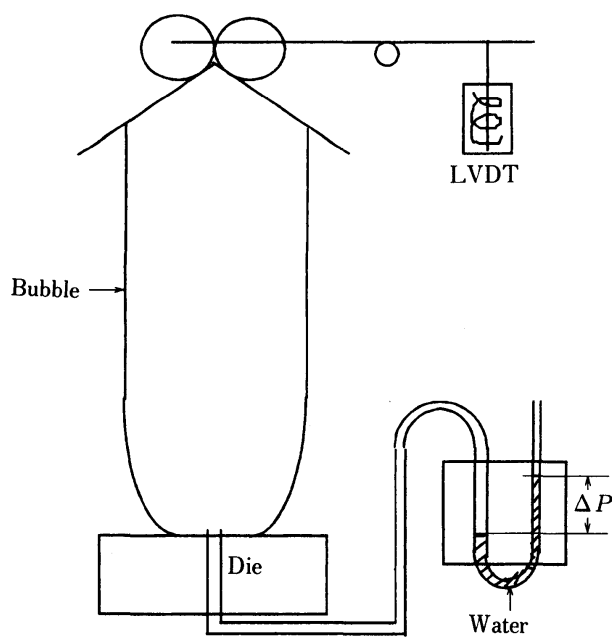

Fig.13 Experimental apparatus for measuring bubble and internal pressure

\section{参 考 文 献}

1) Pearson, J.R.A. and Petrie, C. J. S.:J . Fluid Mech., 40, 1 (1970)

2) Pearson, J.R.A. and Petrie, C. J. S.:J. Fluid Mech., 42, 609 (1970)

3) Pearson, J.R.A. and Petrie, C. J. S. : $J$. Fluid Mech., 42, 609 (1970)

4) Han, C.D. and Park, J. Y.: J. Appl. Polym. Sci., 19, 3277 (1975)

5) Kanai, T. and White, J.L.: Polym. Eng. Sci., 24 (11) , 85 (1984)

6) Kanai, T. : Int. Polym. Processing, 1, 137 (1987)

7）金井俊孝：繊維学会誌，40,28（1984）

8) Petrie, C.J.S.: Rheol. Acta, 12, 92 (1973)

9) Wagner, M.H.: Rheol. Acta, 15, 40 (1978)

10) Luo, X.L. and Tanner, R.I : Polym. Eng. Sci., 25, 620 (1985)

11) Cain, J.J. and Denn, M.M. : Polym. Eng. Sci., 28, 1527 (1988)

12) Babel, K. and Campbell, G.A.: Polm. Process. Soc. Annual Meeting Abstract, 216 (1991)

13）篠原正之, 梶原稔尚, 船津和守：成形加工, 投稿 中

14) Kanai, T. and White, J.L.: J. Polym. Eng., 5, 135 (1985) 